\title{
ANALISIS PENGARUH BOPO, NPL, NIM, DAN LDR TERHADAP PROFITABILITAS PADA BANK UMUM DI INDONESIA PERIODE 2012-2017
}

\author{
Evi Rohmiati *) \\ Winarni $* *$ ) \\ Nina Woelan Soebroto **)
}

\section{ABSTRACT}

This research is performed in order to test the influence of the Operation Expenses to Operations Income (BOPO), Non Performing Loan (NPL), Net Interest Margin (NIM), and Loan to Deposit Ratio (LDR) toward Profitability of Commercial Banks in Indonesia Period 2012-2017.

The sample used is 7 Commercial Banks that entered into the list of Commercial Banks Business Activities 2012-2017. The independent variables in this research are BOPO, NPL, NIM, and LDR. While the dependent variable is Profitability which is represented by Return On Assets (ROA). The analysis model used in this research is Multiple Linear Regression, while the analysis technique in this research using F Statistic Test, $t$ Statistic Test, and Determination Coefficient Test.

The results of this research show that BOPO and NIM have significant influence to Profitability, while NPL and LDR have not significant influence to Profitability. Based on result of regression analysis, it is obtained that Adjusted $R^{2}$ is 0,906, meaning the contribution of independent variable in explaining the dependent variable is $90,6 \%$ and the rest that is $9,4 \%$ is influenced by other variable not examined in this research.

Keywords : Profitability, ROA, BOPO, NPL, NIM, and LDR.

*) Mahasiswa Tugas Akhir Prodi Keuangan dan Perbankan, Jurusan Akuntansi, Politeknik Negeri Semarang

**) Dosen Jurusan Akuntansi, Politeknik Negeri Semarang

\section{PENDAHULUAN}

\section{Latar Belakang Masalah}

Bank merupakan salah satu lembaga keuangan yang berfungsi sebagai financial intermediary atau lembaga perantara antara pihak yang kelebihan dana (surplus) dan pihak yang kekurangan dana (deficit). Dalam hal ini, bank akan membantu pertumbuhan perekonomian Indonesia melalui pengelolaan dana yang tersimpan kemudian dana tersebut dimanfaatkan bagi peningkatan kesejahteraan masyarakat. Perbankan mempunyai peran yang sangat strategis dalam menggerakkan roda perekonomian negara (Arthesa dan Handiman, 2009 : 137).

Rasio profitabilitas merupakan rasio untuk menilai kemampuan perusahaan dalam mencari keuntungan atau laba dalam suatu periode tertentu (Kasmir, 2012:354). Rasio profitabilitas yang digunakan adalah Return On Assets (ROA) karena rasio ini digunakan untuk mengukur 
kemampuan manajemen bank dalam memperoleh keuntungan (laba) secara keseluruhan (Dendawijaya, 2000:120).

Pada dasarnya ROA/Return On Asset merupakan rasio antara laba setelah pajak terhadap total aset. Semakin besar ROA/Return On Asset menunjukkan kinerja keuangan yang semakin baik, karena tingkat pengembalian (return) semakin besar. Apabila ROA/Return On Asset meningkat, berarti profitabilitas perusahaan meningkat (Harun, 2016).

Beberapa faktor yang diduga berpengaruh terhadap Return On Assets (ROA) yaitu BOPO, NPL, NIM, dan LDR.

Biaya Operasional dibandingkan Pendapatan Operasional (BOPO) adalah perbandingan antara biaya operasional dan pendapatan operasional. Rasio biaya operasional digunakan untuk mengukur tingkat efisiensi dan kemampuan bank dalam melakukan kegiatan operasinya (Dendawijaya, 2000 :121). Semakin tinggi biaya operasional maka mengakibatkan hasil ROA yang makin kecil.

Non Performing Loan (NPL) Menurut surat edaran BI No. 3/30/DPNP tanggal 14 Desember 2001, yaitu perbandingan antara kredit bermasalah terhadap total kredit yang diberikan. Semakin tinggi rasio NPL suatu bank, menunjukkan semakin buruk kualitas kreditnya.

Net Income Margin (NIM) merupakan rasio yang menunjukkan kemampuan manajemen bank dalam mengelola aktiva produktifnya untuk menghasilkan pendapatan bunga bersih. Semakin besar rasio ini maka meningkatkan pendapatan bunga atas aktiva produktif yang dikelola bank sehingga kemungkinan suatu bank dalam kondisi bermasalah semakin kecil. (Erna dan Joko, 2017).

Loan to Deposit Ratio (LDR) merupakan rasio untuk mengukur komposisi jumlah kredit yang diberikan dibandingkan dengan jumlah dana masyarakat dan modal sendiri yang digunakan. Besarnya Loan to Deposit Ratio menurut peraturan pemerintah maksimum 110\% (Kasmir, 2012:319). Semakin tinggi LDR maka ROA semakin meningkat dengan catatan bahwa bank tersebut mampu menyalurkan kreditnya dengan optimal.

Rata-rata Return On Assets (ROA) perbankan sebelumnya bisa mencapai 3\% ke atas, tetapi untuk saat ini berat untuk meraih angka tersebut bagi perbankan. ROA seluruh industri perbankan pun turun dalam 10 tahun terakhir (http://mediaindonesia.com). Mengingat pentingnya peranan perbankan di Indonesia, maka lembaga perbankan perlu meningkatkan kinerjanya agar tercipta perbankan yang sehat dan optimal. Tabel 1 menyajikan perkembangan Return On Assets (ROA) 
pada Bank Umum Kegiatan Usaha (BUKU) 4 periode 2012-2017. Bank Umum Kegiatan Usaha (BUKU) 4 dipilih sebagai objek penelitian karena rasio profitabilitas BUKU 4 dalam enam tahun terakhir cenderung menunjukkan penurunan. Selain itu Data OJK sampai Februari 2017 menunjukkan, ROA BUKU 3 sebesar 1,99\% atau naik 57 bps secara tahunan atau year on year. Sedangkan ROA BUKU 4 sebesar 2,7\% atau naik 28 bps secara year on year (www.kontan.co.id). Meskipun di tahun 2017 ROA BUKU 4 mengalami kenaikan namun kenaikannya masih kecil dibandingkan dengan ROA BUKU 3.

\section{Tabel 1}

Return On Assets (ROA) pada Bank Umum Kegiatan Usaha (BUKU) 4 periode 2012-2017 (dalam presentase)

\begin{tabular}{|c|c|c|c|c|c|c|c|}
\hline \multirow{2}{*}{ No. } & \multirow{2}{*}{ Bank } & \multicolumn{6}{|c|}{ Tahun } \\
\hline & & 2012 & 2013 & 2014 & 2015 & 2016 & 2017 \\
\hline 1 & Bank CIMB Niaga & 3,18 & 2,76 & 1,33 & 0,47 & 1,09 & 1,70 \\
\hline 2 & Bank Panin & 1,96 & 1,85 & 2,23 & 1,31 & 1,69 & 1,61 \\
\hline 3 & Bank Mandiri & 3,55 & 3,66 & 3,57 & 3,15 & 1,95 & 2,72 \\
\hline 4 & Bank Rakyat Indonesia & 5,15 & 5,03 & 4,73 & 4,19 & 3,84 & 3,69 \\
\hline 5 & Bank Negara Indonesia & 2,90 & 3,40 & 3,50 & 2,60 & 2,70 & 2,70 \\
\hline 6 & Bank Danamon Indonesia & 2,70 & 2,50 & 1,90 & 1,70 & 2,50 & 3,10 \\
\hline 7 & Bank Central Asia & 3,60 & 3,80 & 3,90 & 3,80 & 4,00 & 3,90 \\
\hline & Rata-rata & 3,29 & 3,29 & 3,02 & 2,46 & 2,45 & 2,77 \\
\hline
\end{tabular}

Sumber: Laporan tahunan tiap Bank Umum Kegiatan Usaha (BUKU) 4 periode 2012-2017 yang telah diolah kembal 


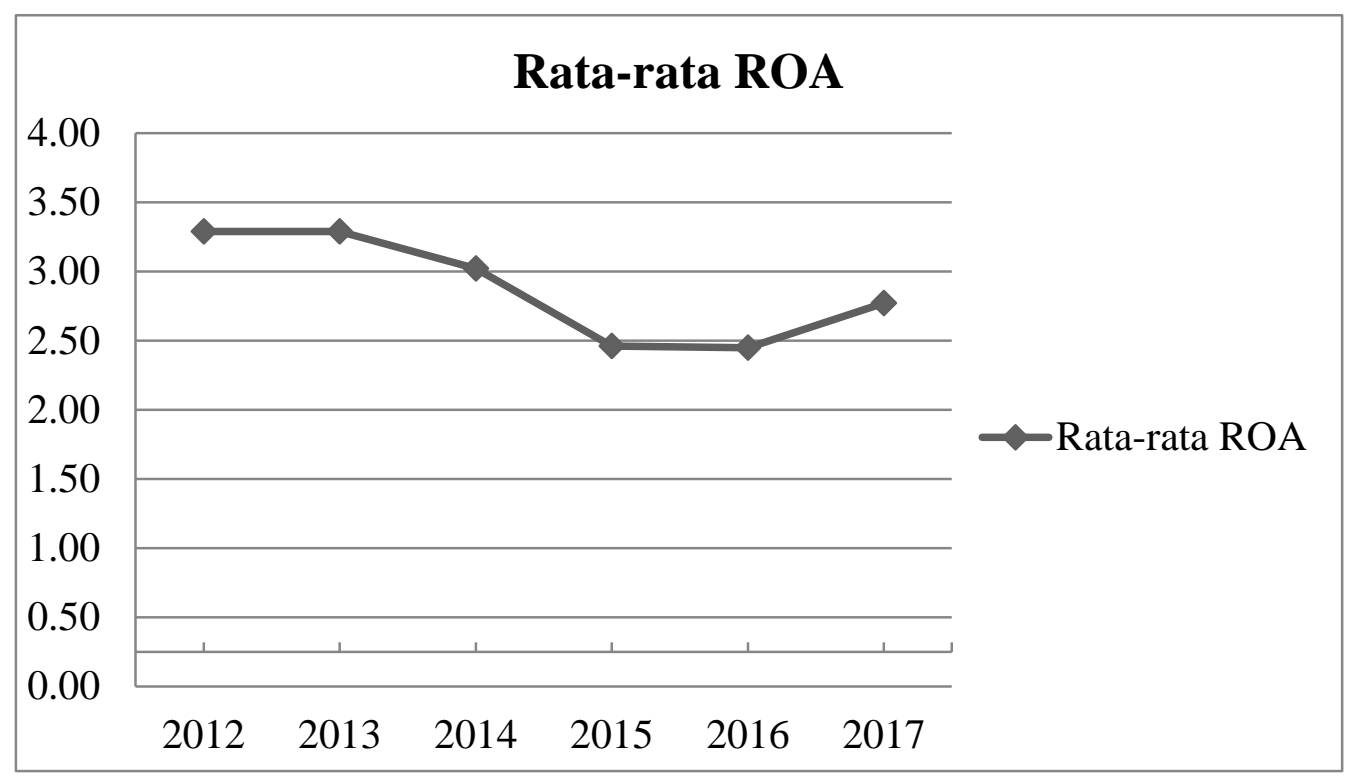

Gambar 1

Return On Assets (ROA) pada Bank Umum Kegiatan Usaha (BUKU) 4 periode 2012-2017 (dalam presentase)

Sumber: Laporan tahunan tiap Bank Umum Kegiatan Usaha (BUKU) 4 periode 2012-2017 yang telah diolah kembali.

Berdasarkan tabel 1 dan gambar 1, sampel data yang memaparkan ROA dari Bank Umum Kegiatan Usaha (BUKU) 4 periode 2012-2017, apabila dilihat secara keseluruhan perkembangan Return On Assets (ROA) masing-masing bank pada Bank Umum Kegiatan Usaha (BUKU) 4 selama tahun 2012 sampai dengan tahun 2017 cenderung menunjukkan penurunan. Rata-rata ROA Bank BUKU 4 pada tahun 2012 dan 2013 menunjukkan angka yang sama (stabil) yaitu 3,29\%; tahun 2014 sebesar 3,02\%; tahun 2015 sebesar 2,46\%; tahun 2016 sebesar 2,45\% dan tahun 2017 sebesar $2,77 \%$. ROA merupakan rasio antara laba sebelum pajak terhadap total aset, semakin besar ROA menunjukkan semakin baik pula profitabilitas suatu bank. Apabila profitabilitas bank mengalami penurunan terus-menerus dapat berakibat pada kebangkrutan.

Berdasarkan uraian latar belakang di atas, maka penulis merasa tertarik untuk melakukan penelitian dengan judul "Analisis Pengaruh BOPO, NPL, NIM, dan LDR Terhadap Profitabilitas pada Bank Umum di Indonesia Periode 2012-2017”. 


\section{Rumusan Masalah}

Berdasarkan latar belakang diatas, maka dapat dirumuskan masalah menjadi, apakah Biaya Operasional dibandingkan Pendapatan Operasional (BOPO), Non Performing Loan (NPL), Net Interest Margin (NIM), dan Loan to Deposit Ratio(LDR) berpengaruh terhadap Profitabilitas pada Bank Umum di Indonesia periode 2012-2017.

\section{KAJIAN TEORI}

\section{Profitabilitas}

Profitabilitas bank adalah kemampuan suatu perusahaan dalam mencari keuntungan atau laba dalam suatu periode tertentu (Kasmir, 2012:354). Tujuan sebuah perusahaan adalah memperoleh laba atau keuntungan yang maksimal, disamping hal-hal lainnya. Manajemen perusahaan dituntut harus mampu untuk memenuhi target yang telah ditetapkan. Besarnya keuntungan yang dicapai harus sesuai dengan yang telah ditargetkan. Untuk mengukur tingkat keuntungan suatu bank, digunakan rasio keuntungan atau rasio profitabilitas.

Return On Assets (ROA)

Menurut Dendawijaya (2000:120) Return On Assets (ROA) merupakan rasio yang digunakan untuk mengukur kemampuan manajemen bank dalam memperoleh keuntungan (laba) secara keseluruhan. Semakin besar Return On Assets (ROA) suatu bank, semakin besar pula posisi bank tersebut dari segi penggunaan aset. Menurut Peraturan Bank Indonesia No. 13/1/PBI/2011, standar terbaik Return On Assets (ROA) adalah lebih dari 1,5\%.

Berikut merupakan formasi dalam menghitung ROA berdasarkan Surat Edaran Bank Indonesia NO. 3/30/DPNP tanggal 14 Desember 2001:

$$
\text { ROA }=\frac{\text { Laba sebelum pajak }}{\text { Rata-rata total aset }} \times 100 \%
$$

\section{Beban Operasional dibandingkan Pendapatan Operasional (BOPO)}

Menurut Pandia dalam Usman (2016) bahwa BOPO/Biaya Operasional Pendapatan Operasional rasio yang sering disebut rasio efisiensi ini digunakan untuk mengukur kemampuan manajemen bank dalam mengendalikan biaya operasional terhadap pendapatan operasional. Semakin kecil rasio ini berarti semakin efisien biaya operasional yang dikeluarkan bank yang bersangkutan sehingga kemungkinan suatu bank dalam kondisi bermasalah semakin kecil. 
Menurut Peraturan Bank Indonesia No. 13/1/PBI/2011, standar terbaik untuk rasio Biaya Opersional dibandingkan Pendapatan Operasional (BOPO) adalah berkisar $80 \%$.

Berikut adalah formula perhitungan Biaya Operasional dibandingkan Pendapatan Operasional (BOPO) menurut Surat Edaran Bank Indonesia NO. 3/30/DPNP tanggal 14 Desember 2001:

$$
\text { BOPO }=\frac{\text { Total Beban Operasional }}{\text { Total Pendapatan Operasional }} \times 100 \%
$$

\section{Non Performing Loan (NPL)}

Rasio NPL adalah perbandingan antara kredit bermasalah terhadap total kredit. Rasio ini menunjukkan kemampuan manajemen bank dalam mengelola kredit bermasalah. Semakin tinggi rasio ini maka akan semakin buruk kualitas kredit bank yang berarti jumlah kredit bermasalah semakin besar, sehingga kemungkinan suatu bank dalam kondisi bermasalah semakin besar. Untuk penilaian bank, Menurut Peraturan Bank Indonesia No. 13/1/PBI/2011 besarnya Rasio Non Performing Loan (NPL) maksimum yang ditetapkan oleh Bank Indonesia adalah sebesar 5\%.

Berikut merupakan formasi dalam menghitung Non Performing Loan (NPL) berdasarkan Surat Edaran Bank Indonesia NO. 3/30/DPNP tanggal 14 Desember 2001:

$$
\text { NPL }=\frac{\text { Kredit Bermasalah }}{\text { Total Kredit }} \times 100 \%
$$

\section{Net Interest Margin (NIM)}

Net Interest Margin (NIM) merupakan rasio yang menunjukkan kemampuan manajemen bank dalam mengelola aktiva produktifnya untuk menghasilkan pendapatan bunga bersih. Semakin besar rasio ini maka meningkatnya pendapatan bunga atas aktiva produktif yang dikelola bank sehingga kemungkinan bank dalam kondisi bermasalah semakin kecil (Almilia dan Herdiningtyas, dalam Mismiwati 2016). Menurut Peraturan Bank Indonesia No. 13/1/PBI/2011, standar terbaik Net Interest Margin (NIM) dari rata-rata perbankan adalah 5\%.

Berikut adalah formula perhitungan Net Interest Margin (NIM) menurut Surat Edaran Bank Indonesia NO. 3/30/DPNP tanggal 14 Desember 2001:

$$
\mathrm{NIM}=\frac{\text { Pendapatan bunga bersih }}{\text { Rata-rata aset produktif }} \times 100 \%
$$




\section{Loan to Deposit Ratio (LDR)}

Menurut kamus Bank Indonesia Loan to Deposit Ratio (LDR) merupakan rasio pembiayaan terhadap dana pihak ketiga yang diterima oleh bank. Besarnya Loan to Deposit Ratio menurut peraturan pemerintah maksimum 110\% (Kasmir, 2012:319), sedangkan menurut Taswan (2006:161) besarnya LDR yang dijinkan adalah berkisar $89 \%$ hingga 115\%. Artinya minimum LDR adalah $89 \%$ dan maksimumnya adalah $115 \%$.

Berikut adalah formula perhitungan LDR menurut Surat Edaran Bank Indonesia No. 3/30/DPNP tanggal 14 Desember 2001 yaitu:

$$
\mathrm{LDR}=\frac{\text { Kredit }}{\text { Dana Pihak Ketiga }} \times 100 \%
$$

\section{Kerangka Pemikiran Teoritis}

Penelitian ini dilakukan dengan empat variabel yang diduga berpengaruh terhadap Return On Assets (ROA) yaitu Biaya Operasional dibandingkan Pendapatan Operasional (BOPO), Non Performing Loan (NPL), Net Interest Margin (NIM), dan Loan to Deposit Ratio(LDR). Dengan demikian dapat dirumuskan kerangka pemikiran teorits dalam penelitian ini adalah sebagai berikut:

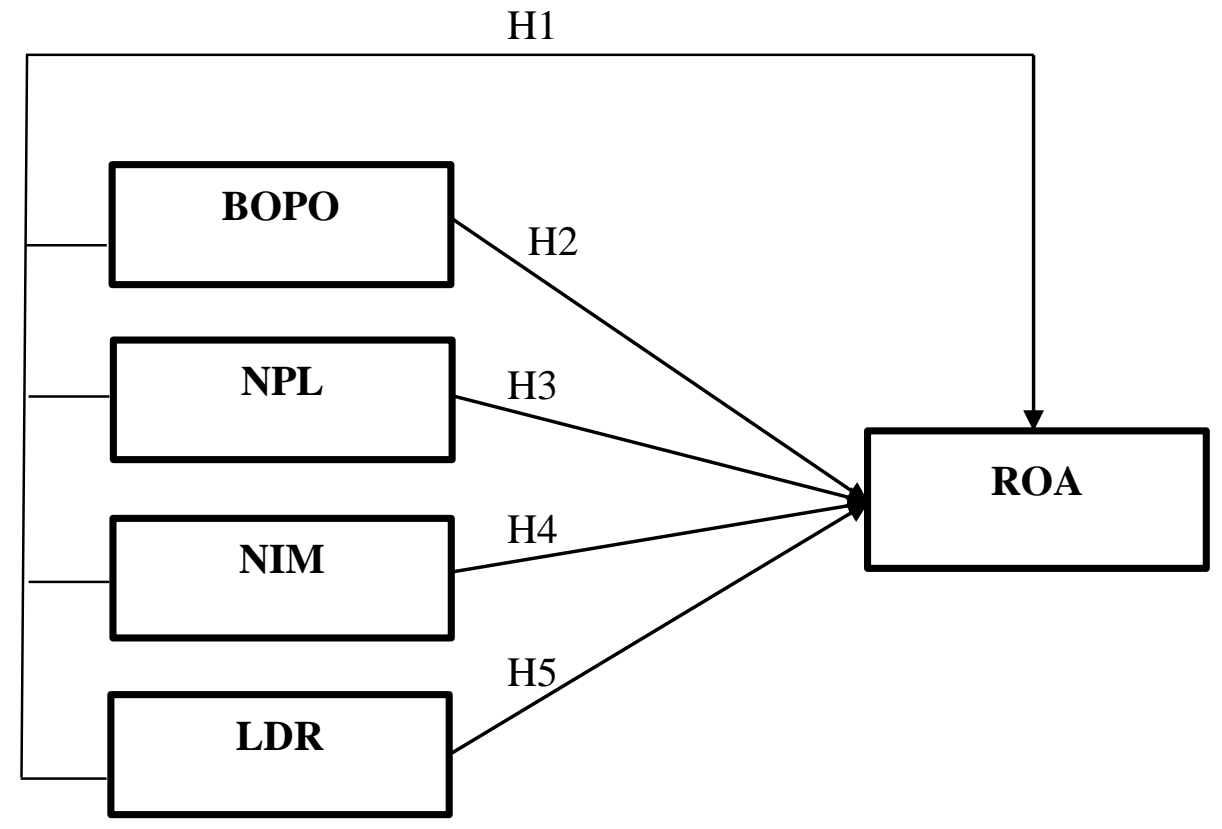

Gambar 2

Kerangka Pemikiran Teoritis antara BOPO, NPL, NIM, dan LDR terhadap ROA

Sumber: Hasil Pengembangan Penelitian untuk Tugas Akhir, 2018 


\section{METODE}

\section{Populasi dan Sampel}

Populasi penelitian ini adalah seluruh bank umum yang ada di Indonesia. Sampel penelitian ini adalah Bank Umum Kegiatan Usaha (BUKU) 4 yang terdiri 7 bank umum di Indonesia yang diambil dengan menggunakan teknik purpose sampling.

\section{Jenis Data dan Sumber Data}

Penelitian ini data yang digunakan adalah data sekunder yang diperoleh dari pengamatan rasiorasio keuangan bank umum yang bersumber dari Laporan Publikasi Otoritas Jasa Keuangan (OJK) dan website resmi bank-bank umum selama tahun 2012 sampai dengan 2017.

\section{HASIL DAN PEMBAHASAN}

\section{Analisis Regresi Linier Berganda}

Untuk mengetahui pengaruh variabel independen $\left(\mathrm{X}_{1}, \mathrm{X}_{2}, \mathrm{X}_{3}, \mathrm{X}_{4}\right)$ yaitu BOPO, NIM, NPL, dan LDR serta variabel dependen yaitu ROA, maka penelitian ini menggunakan model regresi linier berganda. Hasil perhitungan analisis regresi linier berganda dapat dilihat pada tabel 2

\section{Tabel 2}

Hasil Perhitungan Regresi Linier Berganda Coefficients $^{\mathrm{a}}$

\begin{tabular}{|c|c|c|c|c|c|c|c|}
\hline \multirow[t]{2}{*}{ Model } & \multicolumn{2}{|c|}{$\begin{array}{c}\text { Unstandardized } \\
\text { Coefficients }\end{array}$} & \multirow{2}{*}{$\begin{array}{c}\begin{array}{c}\text { Standardized } \\
\text { Coefficients }\end{array} \\
\text { Beta }\end{array}$} & \multirow[t]{2}{*}{$\mathrm{T}$} & \multirow[t]{2}{*}{ Sig. } & \multicolumn{2}{|c|}{$\begin{array}{c}\text { Collinearity } \\
\text { Statistics } \\
\end{array}$} \\
\hline & $\bar{B}$ & $\begin{array}{l}\text { Std. } \\
\text { Error }\end{array}$ & & & & $\begin{array}{c}\text { Toleran } \\
\text { ce }\end{array}$ & VIF \\
\hline (Constant) & 8.915 & .759 & & 11.742 & .000 & & \\
\hline BOPO & -.111 & .011 & -.961 & -9.730 & .000 & .234 & 4.273 \\
\hline 1 NPL & -.030 & .092 & -.025 & -.330 & .743 & .393 & 2.546 \\
\hline NIM & .115 & .036 & .170 & 3.239 & .003 & .826 & 1.211 \\
\hline LDR & .016 & .012 & .111 & 1.326 & .193 & .328 & 3.052 \\
\hline
\end{tabular}

a. Dependents Variable: ROA

Sumber: Data sekunder yang diolah dengan IBM SPSS Statistics 21

Dari tabel 2 maka dapat disusun persamaan regresi linier berganda sebagai berikut:

$$
\text { ROA = 8.915 - 0.111 BOPO - 0.030 NPL + 0.115 NIM + 0.016 LDR + e }
$$

Dari hasil persamaan regresi linier berganda tersebut di atas maka dapat di analisis sebagai berikut: 
1. Konstanta $(\alpha)$ menunjukkan angka sebesar 8.915 bertanda positif, hal ini berarti jika variabelvariabel independen diasumsikan dalam keadaan tetap, maka variabel dependen (ROA) akan mempunyai nilai sebesar 8.915 .

2. Koefisien variabel BOPO sebesar 0.111 dengan arah negatif berarti setiap kenaikan BOPO 1 satuan dengan asumsi bahwa variabel lainnya tetap, maka ROA akan mengalami penurunan sebesar 0.111 satuan. Disisi lain apabila BOPO berkurang sebesar 1 satuan, maka ROA akan mengalami kenaikan sebesar 0.111 satuan.

3. Koefisien variabel NPL sebesar 0.030 dengan arah negatif berarti setiap kenaikan NPL 1 satuan dengan asumsi bahwa variabel lainnya tetap, maka ROA akan mengalami penurunan sebesar 0.030 satuan. Disisi lain apabila NPL berkurang sebesar 1 satuan, maka ROA akan mengalami kenaikan sebesar 0.030 satuan.

4. Koefisien variabel NIM sebesar 0.115 dengan arah positif berarti setiap kenaikan NIM sebesar 1 satuan dengan asumsi bahwa variabel lainnya tetap, maka ROA akan mengalami kenaikan sebesar 0.115 satuan. Disisi lain apabila NIM berkurang sebesar 1 satuan, maka ROA mengalami penurunan sebesar 0.115 satuan.

5. Koefisien variabel LDR sebesar 0.016 dengan arah positif berarti setiap kenaikan LDR sebesar 1 satuan dengan asumsi bahwa variabel lainnya tetap, maka ROA akan mengalami kenaikan sebesar 0.016 satuan. Disisi lain apabila LDR berkurang sebesar 1 satuan, maka ROA mengalami penurunan sebesar 0.016 satuan.

\section{Uji Signifikansi Simultan (Uji Statistik F)}

\section{Tabel 3}

Hasil Uji Statistik F

ANOVA ${ }^{a}$

\begin{tabular}{|l|r|r|r|r|r|}
\hline Model & Sum of Squares & Df & Mean Square & F & Sig. \\
\hline Regression & 44.663 & 4 & 11.166 & 100.330 & $.000^{\mathrm{b}}$ \\
1 Residual & 4.118 & 37 & .111 & & \\
\multicolumn{1}{|c|}{ Total } & 48.781 & 41 & & & \\
\hline
\end{tabular}

a. Dependent Variable: ROA

b. Predictors: (Constant), LDR, NIM, NPL, BOPO

Sumber: Data sekunder yang diolah dengan IBM SPSS Statistics 21

Berdasarkan hasil Uji F di atas dapat di peroleh hasil nilai F hitung sebesar 100.330 dengan tingkat signifikansi 0.000. Karena nilai F hitung lebih besar dari F tabel (tingkat signifikansi 5\%, 
jumlah sampel (n) 42 dan jumlah variabel independen 4) yaitu 2.63 dan nilai signifikansi lebih kecil dari 0.05 atau 5\%, maka dapat diketahui jika variabel-variabel independen secara simultan berpengaruh signifikan terhadap variabel dependen. Hal tersebut berarti Ho ditolak dan Ha diterima, sehingga hipotesis 1 yang menyatakan "Diduga bahwa variabel-variabel Biaya Operasional dibandingkan Pendapatan Operasional (BOPO), Non Performing Loan (NPL), Net Interest Margin (NIM), dan Loan to Deposit Ratio (LDR) secara simultan berpengaruh signifikan terhadap Profitabilitas pada Bank Umum di Indonesia Periode 2012-2017” diterima.

\section{Uji Signifikansi Parsial (Uji Statistik t)}

Hasil uji signifikansi parsial (uji statistik t) dapat dilihat pada tabel 2.

Pengujian hipotesis 2 ini dilakukan menggunakan Uji statistik t dengan diperoleh nilai t hitung sebesar -9.730 dan nilai t tabel sebesar 2.02619 dengan tingkat signifikansi 0.000. Nilai signifikansi lebih kecil dari 0.05 atau 5\% dan t hitung (9.730) > t tabel (2.02619), maka Ho ditolak dan Ha diterima, artinya variabel BOPO secara parsial berpengaruh signifikan terhadap profitabilitas (ROA) pada Bank Umum di Indonesia. Sehingga dapat disimpulkan bahwa hipotesis 2 yang menyatakan "Diduga bahwa variabel Biaya Operasional dibandingkan Pendapatan Operasional (BOPO) secara parsial berpengaruh signifikan terhadap Profitabilitas pada Bank Umum di Indonesia Periode 2012-2017” diterima.

Hal ini sesuai dengan teori yang dikemukakan Pandia dalam Usman (2016) bahwa semakin kecil rasio BOPO berarti semakin efisien biaya operasional yang dikeluarkan bank yang bersangkutan sehingga kemungkinan suatu bank dalam kondisi bermasalah semakin kecil, dalam hal ini yaitu masalah profitabilitas bank. Hasil penelitian ini juga konsisten dengan penelitian yang dilakukan oleh Ayuningrum dan Widyarti (2010).

Pengujian hipotesis 3 ini dilakukan menggunakan Uji statistik $\mathrm{t}$ dengan diperoleh nilai $\mathrm{t}$ hitung sebesar -0.330 dan nilai t tabel sebesar 2.02619 dengan tingkat signifikansi 0.743. Nilai signifikansi lebih besar dari 0.05 atau 5\% dan t hitung (0.330) < t tabel (2.02619), maka Ho diterima dan Ha ditolak, artinya variabel NPL secara parsial berpengaruh tidak signifikan terhadap profitabilitas (ROA) pada Bank Umum di Indonesia. Sehingga dapat disimpulkan bahwa hipotesis 3 yang menyatakan "Diduga bahwa variabel Non Performing Loan (NPL) secara parsial berpengaruh signifikan terhadap Profitabilitas pada Bank Umum di Indonesia Periode 2012-2017”

\section{ditolak.}


Hal ini disebabkan selama periode penelitian rata-rata rasio NPL Bank Umum sebesar 2,3\%. Nilai tersebut masih dibawah yang disyaratkan Bank Indonesia yaitu 5\%. Masih rendahnya NPL menyebabkan Bank Umum masih dapat mengcover kredit bermasalah dari nilai Penyisihan Penghapusan Aktiva Produktif (PPAP) yang ada. Hasil penelitian ini juga konsisten dengan penelitian yang dilakukan oleh Harun (2016).

Pengujian hipotesis 4 ini dilakukan menggunakan Uji statistik $\mathrm{t}$ dengan diperoleh nilai $\mathrm{t}$ hitung sebesar 3.239 dan nilai t tabel sebesar 2.02619 dengan tingkat signifikansi 0.003. Nilai signifikansi lebih kecil dari 0.05 atau 5\% dan t hitung (3.239) > t tabel (2.02619), maka Ho ditolak dan Ha diterima, artinya variabel NIM secara parsial berpengaruh signifikan terhadap profitabilitas (ROA) pada Bank Umum di Indonesia. Sehingga dapat disimpulkan bahwa hipotesis 4 yang menyatakan "Diduga bahwa variabel Net Interest Margin (NIM) secara parsial berpengaruh signifikan terhadap Profitabilitas pada Bank Umum di Indonesia Periode 2012-2017” diterima.

Rasio NIM menunjukkan kemampuan manajemen bank dalam mengelola aktiva produktifnya untuk menghasilkan pendapatan bunga bersih (Almilia dan Herdiningtyas, dalam Mismiwati 2016). Semakin besar NIM yang dicapai oleh suatu bank maka akan meningkatkan pendapatan bunga bersih atas aktiva produktif yang dikelola oleh bank yang bersangkutan. Hasil penelitian ini juga konsisten dengan penelitian yang dilakukan oleh Tan Sau Eng (2013).

Pengujian hipotesis 5 ini dilakukan menggunakan Uji statistik $\mathrm{t}$ dengan diperoleh nilai $\mathrm{t}$ hitung sebesar 1.326 dan nilai t tabel sebesar 2.02619 dengan tingkat signifikansi 0.193. Nilai signifikansi lebih besar dari 0.05 atau 5\% dan t hitung (1.326) < t tabel (2.02619), maka Ho diterima dan Ha ditolak, artinya variabel LDR secara parsial berpengaruh tidak signifikan terhadap profitabilitas (ROA) pada Bank Umum di Indonesia. Sehingga dapat disimpulkan bahwa hipotesis 5 yang menyatakan "Diduga bahwa variabel Loan to Deposit Ratio (LDR) secara parsial berpengaruh signifikan terhadap Profitabilitas pada Bank Umum di Indonesia Periode 2012-2017” ditolak.

Hal ini disebabkan selama periode penelitian rata-rata rasio LDR Bank Umum sebesar 87,9\%, nilai tersebut masih dibawah standar LDR. Menurut Taswan (2006:161) besarnya Loan to Deposit Ratio (LDR) yang baik yaitu berkisar antara $89 \%$ hingga 115\%. Artinya nilai minimum LDR adalah $89 \%$ dan maksimumnya adalah $115 \%$. Masih rendahnya LDR mencerminkan belum optimalnya bank dalam menyalurkan kredit, sehingga LDR tidak banyak berpengaruh pada 
efisiensi bank karena pendapatan bank atas bunga kredit masih kecil. Hasil penelitian ini juga konsisten dengan penelitian yang dilakukan oleh Putri (2015) dan Vernanda dan Widyarti (2016).

Uji Koefisien Determinasi $\left(\mathbf{R}^{2}\right)$

\section{Tabel 4}

Hasil Uji Koefisien Determinasi $\left(\mathbf{R}^{2}\right)$

Model Summary ${ }^{b}$

\begin{tabular}{|l|r|r|r|r|r|}
\hline Model & \multicolumn{1}{|c|}{$\mathrm{R}$} & R Square & $\begin{array}{c}\text { Adjusted R } \\
\text { Square }\end{array}$ & $\begin{array}{c}\text { Std. Error of } \\
\text { the Estimate }\end{array}$ & $\begin{array}{c}\text { Durbin- } \\
\text { Watson }\end{array}$ \\
\hline 1 & $.957^{\mathrm{a}}$ & .916 & .906 & .33360 & 2.024 \\
\hline
\end{tabular}

a. Predictors: (Constant), LDR, NIM, NPL, BOPO

b. Dependent Variable: ROA

Sumber: Data sekunder diolah dengan IBM SPSS Statistics 21

Berdasarkan tabel 4 dapat di ketahui nilai Adjusted $\mathrm{R}^{2}$ sebesar 0.906. Hal ini menunjukkan bahwa sebesar 90,6\% ROA di pengaruhi oleh keempat variabel independen yang digunakan dalam penelitian yaitu BOPO, NPL, NIM, dan LDR. Sedangkan 9,4\% sisanya dijelaskan oleh faktorfaktor lain di luar model yang dianalisis.

\section{PENUTUP}

\section{Kesimpulan}

Kesimpulan dari penelitian ini adalah sebagai berikut:

1. Biaya Operasional dibandingkan Pendapatan Operasional (BOPO), Non Performing Loan (NPL), Net Interest Margin (NIM), dan Loan to Deposit Ratio (LDR) secara simultan berpengaruh signifikan terhadap Profitabilitas pada Bank Umum di Indonesia periode 20122017.

2. Biaya Operasional dibandingkan Pendapatan Operasional (BOPO) secara parsial berpengaruh signifikan terhadap Profitabilitas pada Bank Umum di Indonesia periode 20122017.

3. Non Performing Loan (NPL) secara parsial berpengaruh tidak signifikan terhadap Profitabilitas pada Bank Umum di Indonesia periode 2012-2017.

4. Net Interest Margin (NIM) secara parsial berpengaruh signifikan terhadap Profitabilitas pada Bank Umum di Indonesia periode 2012-2017.

5. Loan to Deposit Ratio (LDR) secara parsial berpengaruh tidak signifikan terhadap Profitabilitas pada Bank Umum di Indonesia periode 2012-2017. 


\section{Keterbatasan Penelitian}

1. Obyek yang digunakan dalam penelitian ini terbatas dengan cakupan Bank Umum Kegiatan Usaha (BUKU) 4 di Indonesia dengan periode penelitian 2012-2017.

2. Variabel-variabel bebas yang digunakan dalam peneltian ini terbatas hanya 4 (empat) variabel, yaitu BOPO, NPL, NIM, dan LDR sedangkan masih ada variabel lain yang tidak digunakan sebagai dasar untuk memprediksi profitabilitas bank, sehingga belum dapat digunakan sebagai alat untuk memprediksi profitabilitas bank secara keseluruhan.

\section{Agenda Penelitian Mendatang}

1. Bagi peneliti selanjutnya diharapkan mampu untuk menambahkan obyek penelitian lebih banyak, sehingga tidak terbatas pada Bank Umum Kegiatan Usaha (BUKU) 4.

2. Guna mengembangkan penelitian selanjutnya disarankan dapat meneliti dengan variabelvariabel lain diluar variabel BOPO, NPL, NIM, dan LDR agar memperoleh hasil yang lebih bervariatif yang dapat menggambarkan hal-hal apa saja yang dapat berpengaruh terhadap profitabilitas bank.

\section{DAFTAR PUSTAKA}

Aliminsyah. 2003. Kamus Istilah Keuangan \& Perbankan. Bandung: Yrama Widya Arthesa, Ade dan Edia Handiman. 2009. Bank dan Lembaga Keuangan Bukan Bank. Jakarta: PT Macanan Jaya Cemerlang.

Bank Indonesia. 2001. Surat Edaran Bank Indonesia Nomor 3/30/DPNP/2001 tentang Pedoman Perhitungan Rasio Keuangan. http://www.bi.go.id. (6 Desember 2017).

-------. 2012. Peraturan Bank Indonesia No. 14/26/PBI/2012 tentang Kegiatan Usaha dan Jaringan Kantor Berdasarkan Modal Inti Bank. http://www.bi.go.id. (6 Desember 2017).

--------. 2015. Peraturan Bank Indonesia No. 17/11/PBI tentang Giro Wajib Minimum Bank Umum dalam Rupiah dan Valuta Asing Bagi Bank Umum Konvensional. http://www.bi.go.id. (6 Desember 2017).

Billian dan Purwanto. 2014. Analisis Pengaruh CAR, NIM, BOPO, dan LDR Terhadap Profitabilitas Bank Persero. Jurnal. Bekasi: Faculty of Business President University.

Dendawijaya, Lukman. 2000. Manajemen Perbankan, Jakarta: Ghalia Indonesia.

Ghozali, Imam. 2009. Aplikasi Analisis Multivariate dengan Program SPSS. Semarang: Badan Penerbit Universitas Diponegoro 
Harun, Usman. 2016. Pengaruh Ratio-Ratio Keuangan CAR, LDR, NIM, BOPO, NPL Terhadap ROA. Jurnal. Manado: Fakultas Ekonomi dan Bisnis Universitas Sam Ratulangi.

Hasan, Iqbal. 2009. Pokok-Pokok Materi Statistik 1 (Statistik Deskriptif). Jakarta: PT Bumi Aksara.

Infobank. 2017. "Peringkat Biaya Operasional Terhadap Pendapatan Operasional (BO/PO)". Desember 2017. Halaman 34.

Infobank. 2017. “Peringkat Komposit Profil Manajemen Risiko". Juli 2017. Halaman 22-23.

Kasmir. 2010. Bank dan Lembaga Keuangan Lainnya. Jakarta: PT Raja Grafindo Persada.

--------. 2012. Manajemen Perbankan. Jakarta: PT Raja Grafindo Persada.

Majidi, Zulfa. 2017. Analisis Pengaruh CAR, NPL, dan LDR Terhadap Profitabilitas pada Perusahaan Perbankan yang Listing di BEI (2014-2016). Jurnal. Malang: Fakultas Ekonomi Universitas Islam Malang.

Mismiwati. 2016. Pengaruh CAR, NIM, BOPO, LDR dan NPL Terhadap ROA (Studi pada PT. BPD SumSel BaBel). Jurnal. Palembang: Fakultas Ekonomi dan Bisnis Islam UIN Raden Fattah Palembang.

Muttaqin, Husein Fajri. 2017. Pengaruh CAR, BOPO, NPL dan LDR Terhadap ROA pada Bank Konvensional di Indonesia (Studi Kasus pada Bank Konvensional yang Terdaftar di BEI). Jurnal Administrasi Bisnis. Samarinda: Fakultas Ilmu Sosial dan Politik Universitas Mulawarman.

Putri, Chandra Chintya. 2015. Pengaruh NPL, LDR, CAR Terhadap Profitabilitas Bank Umum Swasta Nasional Devisa. Jurnal Ilmu dan Riset Manajemen. Surabaya: Sekolah Tinggi Ilmu Ekonomi Indonesia Surabaya.

Redaksi Sinar Grafika. 2002. Undang-Undang Perbankan No. 10 Tahun 1998. Jakarta: Sinar Grafika.

Statistik Perbankan Indonesia. 2017. http://www.bi.go.id. (6 Desember 2017).

Sugiyono. 2007. Metode Penelitian Kuantitatif, Kualitatif dan $R \& D$. Bandung: ALFABETA. Suhardjono, Mudrajad dan Kuncoro. 2011. Manajemen Perbankan Teori dan Aplikasi. Yogyakarta: BPFE Yogyakarta.

Tan Sau Eng. 2013. Pengaruh NIM, BOPO, LDR, NPL dan CAR Terhadap ROA Bank Internasional dan Bank Nasional Go Public Periode 2007-2011. Jurnal Dinamika Manajemen. Jambi: Program Magister Universitas Jambi. 
keunis Majalah IImiah - ISSN No 2302-9315 Vol. 7 No 1 Thn VII Januari 2019

Taswan. 2006. Manajemen Perbankan Konsep, Teknik \& Aplikasi. Yogyakarta: UPP STIM YKPN.

Vernanda dan Widyarti. 2016. Analisis Pengaruh CAR, LDR, NPL, BOPO, dan SIZE Terhadap ROA (Studi pada Bank Umum Konvensional yang Terdaftar di Bursa Efek Indonesia Periode 2010-2015). Jurnal. Semarang: Jurusan Manajemen Fakultas Ekonomika dan Bisnis Universitas Diponegoro. 